\title{
Structural Funds and regional growth: conditions for improving efficiency
}

\author{
Carlos Pinho $^{1} \cdot$ Celeste Varum $^{1} \cdot$ Micaela Antunes $^{2^{*}}$ \\ ${ }^{I}$ Department of Economics, Management and Industrial Engineering, University of Aveiro and GOVCOPP, \\ Portugal \\ ${ }^{2}$ Department of Economics, Management and Industrial Engineering, University of Aveiro and GEMF, Portugal
}

Received: 8 May 2013

Revised: 22 July 2013

Accepted: 5 September 2013

\begin{abstract}
Structural Funds' effectiveness for cohesion promotion within the European Union has been frequently questioned. Given the challenges brought about by recent enlargements to the Central and Eastern Europe and the discussion about limits on EU budget, we analyse the role of EU transfers for growth on a panel of 138 regions in the period 1995-2009. Our main findings are that: (i) Funds effects are not instantaneous; (ii) the effects of Funds over time are intimately related to the level of human capital in the region.
\end{abstract}

Keywords: regional economic growth, Structural Funds, panel data

JEL Classification Codes: C23, O40, R11

\section{Structural Funds and Growth: Literature Assessment}

Along with the economic and social cohesion, the reduction of the regional disparities in Europe has been at the centre of the European initiatives, well reflected on the European Regional Policy. The later has furthermore gained importance, and increased in complexity, in the context of an enlarged European Union, constrained budget and limited growth. The debates and controversies surrounding the approval of the next Multiannual Financial Framework (2014-2020), along with the Agenda 2020 growth strategy goals, show the complexity on this matter. More than ever, research upon the effects of the regional policy and its main instrument, the structural funds, is useful to inform future policy actions.

Despite the high number of studies about the relevance of Structural Funds for growth, there is no consensus on the outcomes. ${ }^{1}$ While some find positive effects (e.g. Cappelen et al.,

\footnotetext{
* Corresponding author. E-mail: maaa@portugalmail.pt.

Citation: Pinho, C., Varum, C. and Antunes, M. (2013) Structural Funds and regional growth: conditions for improving efficiency, Economics and Business Letters, 2(4), 143-149.

${ }^{1}$ Mohl and Hagen (2010) present a summary of major articles about this topic where the main outcomes can be compared.
} 
2003; Becker et al., 2010), others get to inconclusive (e.g. Rodriguez-Pose and Fratesi, 2004; Mohl and Hagen, 2010) or even negative results (e.g. Fagerberg and Verspagen, 1996). Moreover, Dall' erba and Le Gallo (2008) find a non-significant impact of EU transfers over growth, whereas Le Gallo et al. (2011) find a weak effect of Structural Funds on regional growth but very different local impacts.

Recent contributions highlight the need to take the research a step further, in a way to investigate the conditions under which the funds are more effective. On this regard, some studies on European regional growth have considered the use of interaction terms (Cappelen et al., 2003; Llussá and Lopes, 2011; Rodriguez-Pose and Novak, 2011; Becker et al., 2013). Others highlight the need to account for time lagged effects: Mohl and Hagen (2010) and Becker et al. (2010) are notable contributions on this regard, showing that the effect of Funds takes three to four years to be perceptible.

In our opinion, we contribute to the literature in different ways: (i) by including the Member States from the 2004 enlargement; (ii) by exploring the existence of indirect mechanisms between Funds and other variables (mainly human capital) that affect growth; (iii) by analyzing how those effects work over time. We believe these elements to be essential to the discussion about the effectiveness of financial transfers for growth and the conditions under which they are more effective.

\section{Data and model}

We estimate an augmented version of the neoclassical growth model with panel data, as was adopted by Caselli et al. (1996), to avoid omitted variable bias, including both individual and time-specific effects. We include 138 European regions ${ }^{2}$ for the period 1995-2009.

The dependent variable is the annual growth rate of real per capita income $\left(g y_{i, t}\right){ }^{3}$ The set of explanatory variables includes: $\ln \left(y_{i, t-2}\right)$, real per capita income; ln $\left(\right.$ gpop $\left._{i, t-2}\right)$, annual population growth rate; $\ln \left(s_{i, t-2}\right)-\ln \left(s_{i, t-3}\right)$, growth of the investment share; $\ln \left(h c_{i, t-2}\right)$, human capital; $\ln \left(p a t_{i, t-2}\right)$, innovation; and $\ln \left(s f_{i, t-\alpha}\right)$ (with $\left.\alpha=3,4,5\right)$, the (interpolated) ${ }^{4}$ Structural Funds. From previous studies, we expect investment, human capital and innovation to have a positive impact on growth. All variables are lagged twice, to avoid endogeneity and reverse causality. ${ }^{5}$

The growth model is estimated by FE using Rogers's standard errors, robust to heteroscedasticity and autocorrelation (FE Robust) and the Driscoll-Kraay's correction that accounts for spatial dependence, following Hoechle (2007). ${ }^{6}$

\footnotetext{
${ }^{2}$ The 138 regions are distributed as follows: Belgium (3 NUTS1), Czech Republic (8 NUTS2), Denmark (1 NUTS1), Germany (16 NUTS1), Estonia (1 NUTS2), Greece (11 NUTS 2), Spain (17 NUTS2), France (26 NUTS2), Ireland (1 NUTS1), Cyprus (1 NUTS2), Latvia (1 NUTS2), Lithuania (1 NUTS2), Luxembourg (1 NUTS2), Malta (1 NUTS2), Netherlands (4 NUTS1), Poland (16 NUTS2), Portugal (7 NUTS2), Slovenia (2 NUTS2), Slovakia (4 NUTS2), Finland (2 NUTS1), Sweden (2 NUTS1) and the United Kingdom (12 NUTS1). Regional per capita GDP is not available from Eurostat for Austria, Hungary and Italy before 2007 and thus these countries were not considered.

${ }^{3}$ See the Appendix for an explanation on the variables.

${ }^{4}$ To avoid an incomplete series on our key variables (although the number of missing values is low), we use linear interpolation (Stata command ipolate). Mohl and Hagen (2010) also adopt this procedure to their innovation proxy.

${ }^{5}$ Structural Funds are lagged three, four and five years to analyse the length of their effects over time.

${ }^{6}$ We could not perform Pesaran's CD test on residual cross-sectional dependence due to lack of sufficient number of common observations in the panel.
} 


\section{Empirical results}

For inference purposes, we consider only those pairs of regressions where significance of the variable of interest (Funds) is preserved and concentrate on analysing its effects. Table 1 contains the results for the proxy of financial assistance in per capita terms.

Table 1. FE with robust and Driscoll-Kraay's standard errors (Structural Funds per capita)

\begin{tabular}{|c|c|c|c|c|c|c|}
\hline Variables & $\begin{array}{r}\text { Without } \\
\text { FE Robust } \\
\end{array}$ & $\begin{array}{l}\text { teraction } \\
\text { Driscoll- } \\
\text { Kraay } \\
\end{array}$ & $\begin{array}{l}\text { Interactio } \\
\text { FE Robust } \\
\end{array}$ & $\begin{array}{c}\text { th income } \\
\text { Driscoll- } \\
\text { Kraay } \\
\end{array}$ & $\begin{array}{r}\text { Interactio } \\
\text { FE Robust } \\
\end{array}$ & $\begin{array}{c}\text { human capital } \\
\text { Driscoll- } \\
\text { Kraay } \\
\end{array}$ \\
\hline \multirow[t]{2}{*}{$\ln \left(\mathrm{y}_{\mathrm{i}, \mathrm{t}-2}\right)$} & $-0.2563 * * *$ & $-0.2563 * * *$ & $-0.2409 * * *$ & $-0.2409 * * *$ & $-0.2603 * * *$ & $-0.2603 * * *$ \\
\hline & $(-5.531)$ & $(-3.368)$ & $(-4.347)$ & $(-3.346)$ & $(-5.515)$ & $(-3.477)$ \\
\hline \multirow[t]{2}{*}{$\ln \left(\mathrm{s}_{\mathrm{i}, \mathrm{t}-2}\right)-\ln \left(\mathrm{s}_{\mathrm{i}, \mathrm{t}-3}\right)$} & 0.0196 & $0.0196^{*}$ & 0.0190 & 0.0190 & 0.0205 & $0.0205^{*}$ \\
\hline & $(1.468)$ & $(1.791)$ & $(1.431)$ & $(1.625)$ & $(1.533)$ & $(1.819)$ \\
\hline \multirow[t]{2}{*}{$\ln \left(\right.$ gpop $\left._{\mathrm{i}, \mathrm{t}-\mathrm{2}}\right)$} & -0.0192 & -0.0192 & 0.0094 & 0.0094 & -0.0191 & -0.0191 \\
\hline & $(-0.718)$ & $(-0.798)$ & $(0.373)$ & $(0.351)$ & $(-0.649)$ & $(-0.789)$ \\
\hline \multirow[t]{2}{*}{$\ln \left(h c_{i, t-2}\right)$} & $0.0940 * * *$ & $0.0940 * * *$ & $0.1028 * * *$ & $0.1028 * * *$ & $0.1088^{* * * *}$ & $0.1088^{* * * *}$ \\
\hline & $(4.159)$ & (3.112) & $(4.501)$ & $(3.171)$ & $(4.876)$ & $(4.030)$ \\
\hline \multirow[t]{2}{*}{$\ln \left(\right.$ pat $\left._{\mathrm{i}, \mathrm{t}-2}\right)$} & 0.0055 & 0.0055 & 0.0014 & 0.0014 & 0.0053 & 0.0053 \\
\hline & $(1.118)$ & $(0.785)$ & $(0.294)$ & $(0.281)$ & (1.079) & $(0.774)$ \\
\hline \multirow[t]{2}{*}{$\ln \left(\operatorname{sfpc}_{\mathrm{i}, t-3}\right)$} & & & $0.1400 * * *$ & $0.1400^{* *}$ & & \\
\hline & & & $(3.810)$ & $(2.235)$ & & \\
\hline \multirow[t]{2}{*}{$\ln \left(\operatorname{sfpc}_{\mathrm{i},-4-4}\right)$} & $0.0099 * * *$ & $0.0099 *$ & & & $0.0333^{* *}$ & $0.0333 * * *$ \\
\hline & $(4.238)$ & $(1.882)$ & & & $(2.425)$ & $(5.374)$ \\
\hline \multirow[t]{2}{*}{$\ln \left(\mathrm{y}_{\mathrm{i}, \mathrm{t}-2}\right) * \ln \left(\mathrm{sfpc}_{\mathrm{i}, \mathrm{t}-3}\right)$} & & & $-0.0151^{* * *}$ & $-0.0151^{* * *}$ & & \\
\hline & & & $(-3.966)$ & $(-3.966)$ & & \\
\hline \multirow[t]{2}{*}{$\ln \left(h c_{i, t-2}\right) * \ln \left(s f p c_{i, t-4}\right)$} & & & & & $-0.0061 *$ & $-0.0061 * * *$ \\
\hline & & & & & $(-1.730)$ & $(-5.702)$ \\
\hline \multirow[t]{2}{*}{ Constant } & $1.9609 * * *$ & $1.9609 * *$ & $1.9496 * * *$ & $1.9496 * * *$ & $1.9457 * * *$ & $1.9457 * * *$ \\
\hline & $(4.680)$ & $(2.610)$ & $(3.720)$ & $(3.720)$ & $(4.746)$ & $(2.617)$ \\
\hline Time dummies & \multicolumn{2}{|c|}{ Yes } & \multicolumn{2}{|c|}{ Yes } & \multicolumn{2}{|c|}{ Yes } \\
\hline Number of regions & \multicolumn{2}{|c|}{138} & \multicolumn{2}{|c|}{138} & \multicolumn{2}{|c|}{138} \\
\hline Observations & \multicolumn{2}{|c|}{1037} & \multicolumn{2}{|c|}{1037} & \multicolumn{2}{|c|}{1037} \\
\hline Avg. Obs. per Group & \multicolumn{2}{|l|}{7.514} & \multicolumn{2}{|l|}{7.514} & \multicolumn{2}{|c|}{7.514} \\
\hline R2 overall & \multicolumn{2}{|l|}{0.155} & \multicolumn{2}{|l|}{0.144} & \multicolumn{2}{|c|}{0.153} \\
\hline R2 within & \multicolumn{2}{|c|}{0.526} & \multicolumn{2}{|c|}{0.540} & & 29 \\
\hline $\mathrm{R} 2$ between & 0.240 & & 0.244 & & & \\
\hline$p$-value $F$ test & & & & & & 00 \\
\hline $\mathrm{p}$-value $\mathrm{F}$ test time dummies & & & & & & 00 \\
\hline
\end{tabular}

Notes: T-ratio in parentheses. *Significant at $10 \% ; * *$ at $5 \% ; * * *$ at $1 \%$ level.

There is evidence of conditional convergence, being human capital the factor with the most noticeable effect. When only direct impacts are considered, four years lagged Funds play a positive role.

In order to analyse the existence of indirect links, we interact Funds with the income level and with the human capital of the region. The results reveal that three-year lagged Funds affect growth in a positive way, as far as the income level remains below 10630.9 Euros per 
inhabitant. ${ }^{7}$ From the interaction of Funds with human capital we conclude that both impact positively on growth.

The results do not change considerably when we consider the Funds share instead (Table 2).

Table 2. FE with robust and Driscoll-Kraay's standard errors (Structural Funds share)

\begin{tabular}{|c|c|c|c|c|c|c|c|c|}
\hline Variables & $\begin{array}{l}\text { Without i } \\
\text { FE Robust }\end{array}$ & $\begin{array}{c}\text { teraction } \\
\text { Driscoll- } \\
\text { Kraay } \\
\end{array}$ & FE Robust & \multicolumn{4}{|c|}{ Interaction with human capital } & $\begin{array}{c}\text { Driscoll- } \\
\text { Kraay }\end{array}$ \\
\hline \multirow[t]{2}{*}{$\ln \left(\mathrm{y}_{\mathrm{i}, \mathrm{t}-2}\right)$} & $-0.1845 * * *$ & $-0.1845 * *$ & $-0.1972 * * *$ & $-0.1972 * * *$ & $-0.2253^{* * *}$ & $-0.2253^{* * *}$ & $-0.2301 * * *$ & $-0.2301 * * *$ \\
\hline & $(-4.373)$ & $(-2.499)$ & $(-4.909)$ & $(-2.640)$ & $(-5.106)$ & $(-2.846)$ & $(-5.568)$ & $(-2.852)$ \\
\hline \multirow[t]{2}{*}{$\ln \left(\mathrm{s}_{\mathrm{i}, \mathrm{t}-2}\right)-\ln \left(\mathrm{s}_{\mathrm{i}, \mathrm{t}-\mathrm{3}}\right)$} & $0.0241 *$ & $0.0241^{*}$ & 0.0206 & 0.0206 & $0.0229 *$ & $0.0229^{*}$ & 0.0159 & 0.0159 \\
\hline & $(1.789)$ & $(1.735)$ & $(1.553)$ & $(1.528)$ & $(1.710)$ & $(1.710)$ & $(1.192)$ & $(1.208)$ \\
\hline \multirow[t]{2}{*}{$\ln \left(\right.$ gpop $\left._{\mathrm{i}, \mathrm{t}-2}\right)$} & -0.0145 & -0.0145 & -0.0223 & -0.0223 & -0.0208 & -0.0208 & -0.0246 & -0.0246 \\
\hline & $(-0.611)$ & $(-0.624)$ & $(-0.841)$ & $(-0.905)$ & $(-0.719)$ & $(-0.838)$ & $(-0.838)$ & $(-0.936)$ \\
\hline \multirow[t]{2}{*}{$\ln \left(\mathrm{hc}_{\mathrm{i}, \mathrm{t}-2}\right)$} & $0.1087 * * *$ & $0.1087 * * *$ & $0.1298 * * *$ & $0.1298 * * *$ & $0.1144 * * *$ & $0.1144 * * *$ & $0.1367 * * *$ & $0.1367 * * *$ \\
\hline & $(5.090)$ & $(3.834)$ & $(7.150)$ & $(4.328)$ & $(4.855)$ & $(3.929)$ & $(6.437)$ & $(4.279)$ \\
\hline \multirow[t]{2}{*}{$\ln \left(\mathrm{pat}_{\mathrm{i},-2-2}\right)$} & 0.0086 & 0.0086 & $0.0090^{*}$ & 0.0090 & 0.0067 & 0.0067 & 0.0083 & 0.0083 \\
\hline & $(1.635)$ & $(1.343)$ & (1.694) & $(1.484)$ & (1.289) & $(0.925)$ & $(1.630)$ & $(1.323)$ \\
\hline \multirow[t]{2}{*}{$\ln \left(\right.$ sfshare $\left._{i, t-3}\right)$} & $-0.0467 * * *$ & $-0.0467 *$ & $0.1515^{* *}$ & $0.1515^{* * *}$ & & & & \\
\hline & $(-4.670)$ & $(-1.656)$ & $(2.008)$ & $(2.870)$ & & & & \\
\hline \multirow[t]{2}{*}{$\ln \left(\right.$ sfshare $\left._{i, t-4}\right)$} & & & & & $0.2106^{* * *}$ & $0.2106^{* * *}$ & & \\
\hline & & & & & $(2.741)$ & $(5.879)$ & & \\
\hline \multirow[t]{2}{*}{$\ln \left(\right.$ sfshare $\left._{\mathrm{i}, \mathrm{t}-\mathrm{s}}\right)$} & & & & & & & $0.3136^{* * *}$ & $0.3136 * * *$ \\
\hline & & & & & & & $(3.768)$ & $(5.070)$ \\
\hline \multirow[t]{2}{*}{$\ln \left(\mathrm{hc}_{\mathrm{i},-2-2}\right) * \ln \left(\right.$ sfshare $\left._{\mathrm{i},-\mathrm{-}-3}\right)$} & & & $-0.0509 * * *$ & $-0.0509 * * *$ & & & & \\
\hline & & & $(-2.707)$ & $(-3.209)$ & & & & \\
\hline \multirow[t]{2}{*}{$\ln \left(\mathrm{hc}_{\mathrm{i}, \mathrm{t}-2}\right) * \ln \left(\right.$ sfshare $\left._{\mathrm{i}, \mathrm{t}-\mathrm{u}}\right)$} & & & & & $-0.0525^{* * *}$ & $-0.0525^{* * *}$ & & \\
\hline & & & & & $(-2.746)$ & $(-6.725)$ & & \\
\hline \multirow[t]{2}{*}{$\ln \left(\mathrm{hc}_{\mathrm{i}, \mathrm{t}-2}\right) * \ln \left(\mathrm{sfshare}_{\mathrm{i}, \mathrm{t}-\mathrm{s}}\right)$} & & & & & & & $-0.0868 * * *$ & $-0.0868 * * *$ \\
\hline & & & & & & & $(-3.910)$ & $(-4.924)$ \\
\hline \multirow[t]{2}{*}{ Constant } & $1.2529^{* * *}$ & 1.2529 & $1.2719^{* * *}$ & 1.2719 & $1.6029^{* * *}$ & $1.6029 * *$ & $1.5591 * * *$ & $1.5591^{*}$ \\
\hline & (3.214) & $(1.608)$ & $(3.526)$ & (1.633) & $(4.205)$ & $(2.015)$ & $(4.345)$ & $(1.897)$ \\
\hline Time dummies & \multicolumn{2}{|c|}{ Yes } & \multicolumn{2}{|c|}{ Yes } & \multicolumn{2}{|c|}{ Yes } & \multicolumn{2}{|c|}{ Yes } \\
\hline Number of regions & \multicolumn{2}{|c|}{138} & \multicolumn{2}{|c|}{138} & \multicolumn{2}{|c|}{138} & \multicolumn{2}{|c|}{138} \\
\hline Observations & \multicolumn{2}{|c|}{1037} & \multicolumn{2}{|c|}{1037} & \multicolumn{2}{|c|}{1037} & & \\
\hline Avg. Obs. per Group & 7.514 & & 7.514 & & 7.514 & & 7.514 & \\
\hline $\mathrm{R} 2$ overall & 0.188 & & 0.178 & & 0.163 & & 0.158 & \\
\hline R2 within & & & & & & 20 & & \\
\hline $\mathrm{R} 2$ between & 0.225 & & 0.212 & & 0.230 & & 0.212 & \\
\hline p-value F test & & & & & & 00 & & \\
\hline dummies & & & & & & 00 & & \\
\hline
\end{tabular}

Notes: T-ratio in parentheses. *Significant at $10 \% ; * *$ at $5 \% ; * * *$ at $1 \%$ level.

\footnotetext{
${ }^{7}$ Some regions from 7 countries of the 2004 enlargement, as well as some Greek and Portuguese regions meet this condition for some years of the analysis. The remaining exceeds this limit.
} 
With no interaction terms, three-year lagged financial aid impact negatively on growth. However the impact of Funds depends on the levels of human capital. Three-, four- and fiveyear lagged Funds impact positively on growth when human capital levels are lower than 19.6, 55.2 and $37.1 \%$, respectively. Since education standards are positively correlated with income levels, this indicates that the returns from financial assistance have been higher in less developed areas. ${ }^{8}$

\section{Concluding remarks}

Our findings suggest the existence of conditional convergence among European regions. Moreover, human capital is the only variable that robustly explains growth. Structural Funds' impact on growth occurs throughout time and depends on human capital performance in the years following financial assistance. Apparently, financial aid is more effective in less developed regions but it may originate a moral hazard problem for creating lack of incentives for regions to go beyond the threshold limit of assistance.

Acknowledgements. We are very grateful to the reviewers for the valuable comments on our paper. Financial support from FCT is gratefully acknowledged (Pest-C/CJP/UI4058/2011-GOVCOPP).

\section{References}

Aiello, F. and Pupo, V. (2012) Structural funds and the economic divide in Italy, Journal of Policy Modeling, 34(3), 403-418.

Becker,S., Egger, P. and von Elrich, M. (2010) Going NUTS: the effect of EU Structural Funds on regional performance, Journal of Public Economics, 94, 578-590.

Becker, S., Egger, P. and von Ehrlich, M. (2013) Absorptive capacity and the growth and investment effects of regional transfers: a regression discontinuity design with heterogeneous treatment effects, American Economic Journal: Economic Policy (forthcoming).

Cappelen, A., Castellacci, F., Fagerberg, J. and Verspagen, B. (2003) The impact of EU regional support on growth and convergence in the European Union, Journal of Common Market Studies, 41(4), 621-644.

Caselli, F., Esquivel, G. and Lefort, F. (1996) Reopening the convergence debate: a new look at crosscountry growth empirics, Journal of Economic Growth, 1(3), 363-389.

Council of the European Union (2013) $3220^{\text {th }}$ Economic and Financial Affairs Council Meeting, $12^{\text {th }}$ February, Brussels.

Dall'erba, S. and Le Gallo, J. (2008) Regional convergence and the impact of Structural Funds over 1989-1999: a spatial econometric analysis, Papers in Regional Science, 87(2), 219-244.

European Commission (1996) $7^{\text {th }}$ Annual Report on the Structural Funds 1995, Brussels.

European Commission (1997) $8^{\text {th }}$ Annual Report on the Structural Funds 1996, Brussels.

European Commission (1998) $9^{\text {th }}$ Annual Report on the Structural Funds 1997, Brussels.

European Commission (1999) 10 $10^{\text {th }}$ Annual Report on the Structural Funds 1998, Brussels.

European Commission (2011) Statistical Annex of the European Economy, Directorate General Economic and Financial Affairs, Spring.

\footnotetext{
${ }^{8}$ Aiello and Pupo (2012) question the apparently higher returns from Funds over income growth occurring in Southern Italian regions. The authors argue that the higher amounts of transfers received justify their higher (positive) impact on growth in less developed regions. Thus, according to them Funds end up working as income supporter rather than a long-term incentive for growth. Moreover, Becker et al. (2013) find significantly positive effects of Objective 1 transfers over European regional growth only when sufficiently high levels of human capital and government quality are attained. Unless the region's absorptive capacity reaches an appropriate level, inefficiency prevents Funds from having a medium-term impact on growth.
} 
Fagerberg, J. and Verspagen, B. (1996) Heading for divergence? Regional growth in Europe reconsidered, Journal of Common Market Studies, 34(3), 431-448.

Hoechle, D. (2007) Robust standard errors for panel regressions with cross-sectional dependence, The Stata Journal, 7(3), 281-312.

Le Gallo, J., Dall'erba, S. and Guillian, R. (2011) The local versus global dilemma of the effects of Structural Funds, Growth and Change, 42(4), 466-490.

Llussá, F. and Lopes, J. (2011) Regional growth in Europe: the role of European and national policies, FEUNL Working Paper Series, WP554.

Mohl, P. and Hagen, T. (2010) Do EU Structural Funds promote regional growth? New evidence from various panel data approaches, Regional Science and Urban Economics, 40, 353-365.

Rodriguez-Pose, A. and Fratesi, U. (2004) Between development and social policies: the impact of European Structural Funds in Objective 1 regions, Regional Studies, 38(1), 97-113.

Rodriguez-Pose, A. and Novak, K. (2011) Learning processes and economic returns in European cohesion policy, Working Papers Series in Economics and Social Sciences, 2011/17, September, IMDEA Institute.

\section{Appendix}

- $y_{i, t}-$ Real per capita Gross Domestic Product (Euros per inhabitant)

Computed by the authors using data on: (i) GDP at current market prices (Million euro (from 1.1.1999)/Million ECU (up to 31.12.1998)), (ii) Price deflator GDP at market prices (national currency; annual percentage change) and (iii) Annual average population (1 000).

Data Sources: (i) Eurostat, Regional Economic Statistics (data extracted on $6^{\text {th }}$ November 2012); (ii) European Commission (2011) - Given that regional price indexes are not available, we converted nominal into real figures using national GDP deflator assuming that for each region of a given country, the price index is the same; (iii) Eurostat, Regional Demographic Statistics (data extracted on $20^{\text {th }}$ November 2012).

- $g y_{i, t}$ - Annual growth rate of real per capita GDP (annual logarithmic difference of real per capita GDP)

- $g p o p_{i, t}$ - Annual growth rate of population (includes 5\% for the rates of capital depreciation and technological progress)

Computed by the authors using data on "Annual average population (1 000)".

Data Source: Eurostat, Regional Demographic Statistics (data extracted on 20 ${ }^{\text {th }}$ November 2012).

- $s_{i, t}-$ Investment share (\% of GDP)

Computed by the authors using data on: (i) Gross fixed capital formation (Million euro (from 1.1.1999)/Million ECU (up to 31.12.1998)) and (ii) GDP at current market prices (Million euro (from 1.1.1999)/Million ECU (up to 31.12.1998)).

Data Source: (i) and (ii) Eurostat, Regional Economic Statistics

- $h c_{i, t}-$ Human capital (students in tertiary education as a $\%$ of the population aged 20-24 years)

Data Source: Eurostat, Regional Education Statistics (data extracted on $6^{\text {th }}$ November 2012) 
- $p_{a t} t_{i, t}$ - Patents (per million of inhabitants)

Computed by the authors using data on: (i) Number of total patent applications to the European Patents Office (EPO) by priority year and (ii) Annual average population (1 000).

Data Sources: (i) Eurostat, Regional Science and Technology Statistics (data extracted on $16^{\text {th }}$ January 2013) and (ii) Eurostat, Regional Demographic Statistics.

- $\quad s f p c_{i, t}$-Interpolated real per capita Structural Funds (Euros per inhabitant)

Computed by the authors using data on: (i) payments for 1995-1998; (ii) calculation of payments for 1999 as the difference between commitments and payments in 1994-1998; (iii) payments for 20002009; (iv) Price deflator GDP at market prices (national currency; annual percentage change) and (v) Annual average population (1 000).

Data Sources: (i) European Commission (1996; 1997; 1998; 1999); (ii) European Commission (1999); (iii) European Commission - DG Regional and Urban Policy (data sent on $12^{\text {th }}$ December 2012 following a formal request); (iv) European Commission (2011) and (v) Eurostat, Regional Demographic Statistics.

- $\quad s f$ share $_{i, t}$-Interpolated Structural Funds share (\% GDP)

Computed by the authors using data on: (i) payments for 1995-1998; (ii) calculation of payments for 1999 as the difference between commitments and payments in 1994-1998; (iii) payments for 20002009; (iv) GDP at current market prices (Million euro (from 1.1.1999)/Million ECU (up to 31.12.1998))

Data Sources: (i) European Commission (1996; 1997; 1998; 1999); (ii) European Commission (1999); (iii) European Commission - DG Regional and Urban Policy; (iv) Eurostat, Regional Economic Statistics. 